\title{
EVALUATION OF TWO GROUND SPRAYING EQUIPMENTS FOR CONTROLLING SPINY BOLLWORM Earias insulana (BOISD.) IN COTTON FIELD
}

\author{
Rehab, A. A. Dar; M. S. M. Salem; Hemat, Z. Moustafa and
} Nabiela, S. A. Hiekel

Plant Protection Res.instit.Agric.Res.Center, Dokki, Giza.

\begin{abstract}
Three insecticides; Selecron, Trebon and Patron were sprayed using Knapsack motor sprayer Cifarilli (20 L./Fed.) and Economy Micron ULVA (15 L./Fed.) in cotton field infested with the cotton spiny bollworm Earias insulana (Boisd.) larvae during 2014 cotton season at Qaha district, Qalyoubia Governorate. The spectrum of droplets size ranging between 140-169 microns (VMD) with sufficient number ranging from 14-276 droplets $/ \mathrm{cm}^{2}$. The productivity of motor sprayer Cifarilli was $12 \mathrm{Fed} . /$ day. It was the best equipment, but the lowest productivity was 3.04 Fed./day by using Economy Micron ULVA. Results indicated that Trebon and Selecron insecticides were almost behave to be equitoxic effective in controlling larvae of cotton bollworm on cotton plants than the Patron insecticide with Economy Micron ULVA (15 L./Fed.) followed by Knapsack motor Cifarilli sprayer (20L./Fed.). The efficiency of the tested insecticides could be descendingly arranged as follows: Trebon, Selecron and Patron. The corresponding general reduction rates were $91.10,55.99$ and $92.51 \%$ in case of using Micron ULVA equipment and $91.13,55.19$ and $92.20 \%$ in case of using Knapsack motor Cifarilli sprayer, respectively. Data showed that, low volume spraying may be recommended because of reducing the time lost in the process filling the machines of reducing the time lost of the spray solution on the plant leaves and
\end{abstract} saving the lost spray via run off on the ground.

Keywords: Earias insulana - Selecron - Batron - Trebon - Knapsack motor sprayer Cifarilli (20 L./Fed.) and Economy Micron ULVA (15L./Fed.).

\section{INTRODUCTION}

The spiny bollworm Earias insulana (Boisd.) (Lepidoptera: Noctuidae) is considered as a major lepidopteron pest of many crops and distributed in North Africa and Sub continent (Indo-Pak) Abdul-Naser et al. (1973), spiny bollworm is main cotton pest, larvae infesting bolls, damaging cotton squares, flower buds, flowers, seeds and fiber, especially at the late growing stage of the cotton plants that cause decreasing in the quality and quantity in the lint and oil of the obtained yield Salem (2008).

During the cotton-growing season, chemical control is still one of the major tools for controlling bollworms. The control of this pest depended on the stages, which are found outside the fruit bodies, mainly egg, newly hatched larvae as well as moths. So, it is important to determine the generations of the pest and the time of insecticidal application with the appearance of the target stage Zaki (2006).

Insect growth regulators (IGRs) have a more specific mode of action on pests and are not highly toxic to non- target organisms when compared to many conventional insecticides. These characteristics allowed the use of 
chitin synthesis inhibitors to be included promising in Integrated Pest Management programs (IPM) (El- Shennawy 2009 and Kandil et al. 201r).

In the present study, considerable effort was devoted to search for some new compounds containing pyrethriod and IGR that have insecticidal activities against the spiny bollworm which represents one of the most destructive cotton pests in Egypt and many other countries beside one organophosphorus compound. Cotton plants were sprayed with the previous compounds using Knapsack motor (Cifarilli) and Economy Micron ULVA sprayer to study the relationship between spray quality and the infestation percentages of $E$. insulana.

\section{MATERIALS AND METHODS}

\section{1-Insecticides used:}

- etofenprox (Pyrethroid): Trebon 30\%EC.

Chemical name: (2,(4-ethoxyphenyl)-2-methylpropyl 3-phenoxybenzyl ether).

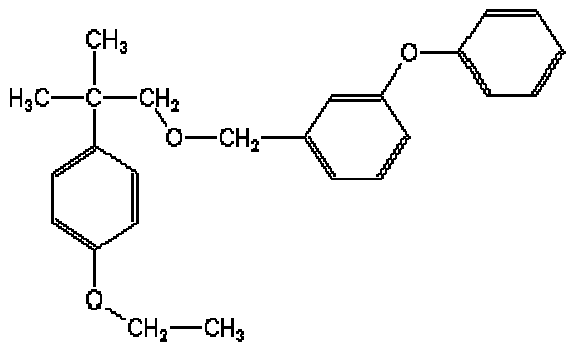

- diflubenzuron (Chitin synthesis inhibitor): Patron 25\% WP.

Chemical name: N-[[(4-chlorophenyl)amino]carbonyl]-2,6-difluorobenzamide.<smiles>O=C(NC(=O)C1C(Cl)C=CCC1F)NC1CC2CCC(C1)C2(F)F</smiles> 
-profenofos (Organophosphorus): Selecron $72 \%$.

Chemical name:O-(4-bromo-2-chloropheny) phosphorothioate.

O-ethyl S-propyl<smiles>CCCOP(=O)(OCC)Oc1ccc(Br)cc1I</smiles>

\section{2-Spraying equipment tested on cotton field:}

Two ground application machines were selected to perform the scope of this work, as commonly used equipment in applying pesticides on cotton plants.

The tested equipment could be represented according to the technical categorization mentioned in Tables (1\&2).

Calculations of productivity and rate of performance were recorded as described by Hindy (1992).

Table (1): Techno-Operational data of the Economy-Micron - ULVA sprayer used in lab.

\begin{tabular}{|c|c|c|}
\hline Item & $\begin{array}{l}\text { Spining disc } \\
\text { ULVA sprayer }\end{array}$ & Remarks \\
\hline Type of spraying & Target & Direct spray \\
\hline Nozzle type & Rotary (spinning disc ) & Restrictor \\
\hline Number of nozzles & 1 & \\
\hline Spray tank (L.) & $1+10$ & 10 L. spray attached. \\
\hline Rate of application (L/fed.) & 15 & \\
\hline Working speed (Km/h.) & 2.4 & $\pm 5 \%$ \\
\hline Effective swath width (m.) & 1.0 & \\
\hline Flow rate (L/min.) & 0.150 & Total of the sprayer \\
\hline Spray height (m.) & 0.5 & \\
\hline Productivity * (fed./h.) & 0.571 & \\
\hline Rate of performance* (fed./day) & 3.04 & daily hours $=8 \mathrm{~h} . \simeq$ \\
\hline
\end{tabular}

* Number of spraying hours $=8$ hours daily.

* Calculations of productivity and rate of performance after Hindy (1992).

3-Calibration and performance adjustment of the tested equipment: - Collection and measurement of Spray deposit:

- Collection of spray deposit

Before spraying each cotton field treatments, a sampling line was constructed of five wire holder fixed in diagonal line inside each treatment to collect lost spray between plants; each wire holder top has a fixed water sensitive paper (Novartis Cards) on it. Also, each five cotton plants, the water sensitive paper cards were put at three levels of cotton plant; upper, middle and lower to collect the droplets deposit on cotton leaves ,were designed according to the method described by Hindy (1989). All cards were collected 
and transferred carefully to the laboratory for measuring and calculating the number of droplets $/ \mathrm{cm}^{2}$ and its volume (VMD) in all treatments.

able (2):Techno-Operational data of certain ground sprayers applied on cotton field during season (2014).

\begin{tabular}{|l|c|}
\hline \multicolumn{1}{|c|}{ Type of sprayer } & $\begin{array}{c}\text { Motorized Knapsack sprayer } \\
\text { Cifarilli }\end{array}$ \\
\hline Item & Cifarilli \\
\hline Model & Italy \\
\hline Manufacturing & - \\
\hline The pump & Mechanical Pneumatic \\
\hline Type of atomization & Pneumatic \\
\hline Nozzle type & One \\
\hline Number of nozzles & - \\
\hline Pressue (bar) & 20.0 \\
\hline Total Tank capacity (L.) & 20.0 \\
\hline Rate of application (L/fed.) & 2.4 \\
\hline Working speed (Km/h.) & 5.0 \\
\hline Swath width (L/m) & 1.0 \\
\hline Flow rate (L/min.) & 0.5 \\
\hline Spray height (m.) & Drift \\
\hline Type of spraying & 12.2 \\
\hline Sprayer weight (Kg) & 2.85 \\
\hline Productivity (Fed./h.) & 12.0 \\
\hline Rate of performance (Fed./day) & 2 \\
\hline No. of worker's & \\
\hline
\end{tabular}

* Number of spraying hours $=8$ hours daily.

* Calculations of productivity and rate of performance after Hindy (1992).

-Determination of spray deposit:

Number and size of blue spots (deposited droplets) on water sensitive papers (Novartis cards) were measured with a special scaled monocular lens (Strüben)®. The volume mean diameter (VMD) and number of droplets in one square centimeter $\left(\mathrm{N} / \mathrm{cm}^{2}\right)$ were estimated according to Hindy (1992).

\section{4-Execution of field experiments:}

\section{- Arrangements of the experiments}

Field experiments were carried out on April $15^{\text {th }}$ during 2014 cotton season at Qaha district, Qalyoubia Governorate, cultivated with Giza 86 cotton variety. The experimental design was randomized complete block with 3 replicates, the whole cultivated area $\left(700 \mathrm{~m}^{2}\right)$ was divided into equally 6 plots, each plot was treated with one of the tested compounds as well as one of the tested equipment; while the remaining plot was left as control. Cotton seeds were sown at $20 \mathrm{~cm}$ distance between hills. Spraying of the tested insecticides took place on cotton plants three times in July, $7^{\text {th }}, 21^{\text {st }}$ and $4^{\text {th }}$ August, respectively, with two motor sprayers (Cifarilli, Knapsack-motor sprayer and Economy 
Micron ULVA sprayer). Each compound was applied individually. The experiments were done under local meteorological conditions of $32^{\circ} \mathrm{C}$ average temperatures, $60 \%$ R.H. and $4.6 \mathrm{~m} / \mathrm{sec}$. as an average wind velocity during experiment.

To evaluate the effect of the three treatments against spiny bollworm, samples of 25 bolls/ plot were randomly picked before and week after application. Sampling continued weekly until harvest. The collected bolls were transported to the laboratory, where they were carefully dissected and percent of larval infestation was recorded and the reduction percentages in green boll (or increase) infestation were determined according to Henderson and Tilton (1955).

\section{RESULTS AND DISCUSSION}

Data presented in Table (3), showed that application of the tested pesticides with Micron ULVA sprayer caused significant reduction in percentages of infested cotton bolls caused by the spiny bollworm $E$. insulana. It was obvious that the reduction percentages in the green bolls caused by $E$. insulana using Micron ULVA sprayer increased gradually from July till September. In case of Selecron treatment, the reduction percentages in the green bolls infestation during July, August and September were 80.17, 92.96 and $93.89 \%$, respectively and $43.80,48.89$ and $66.51 \%$; respectively for Patron application. On the other hand the reduction percentages in the green bolls infested by this pest associated to Trebon spraying recorded $81.82,90.07$ and $94.57 \%$; respectively during the three months that mentioned previously.

As shown in Table (3), Trebon is considered the most promising insecticide for controlling $E$. insulana followed by Selecron compound. On the other hand, Patron treatment showed the least reduction in the green bolls infestation caused by the spiny bollworm. General reduction percentages in the green bolls infestation caused by $E$. insulana larvae in the whole season associated to the treatments with Selecron, Patron and Trebon were 91.15, 55.99 and $92.51 \%$; respectively.

As shown in Table (3), rates of infestation with $E$. insulana in the plot treated with Trebon were lower by $8.33 \& 67.65 ; 15.79 \& 88.41 ; 11.11 . \& 83.79$ and $11.75 \& 82.98 \%$ during the months of July, August, September and the whole season, respectively compared with the two plots applied with Selecron and Patron. On the other hand, rates of infestation in the plot received Selecron were lower by $64.71,86.23,81.76$ and $80.71 \%$ during the months of July, August, September and the whole season; respectively. 
Table (3): Effect of spraying three tested compounds on infestation percentages by spiny bollworm $E$. insulana larvae during season 2014 with Micron ULVA sprayer.

\begin{tabular}{|c|c|c|c|c|}
\hline Inspection date & Control & Selecron & Patron & Trebon \\
\hline $30 / 6$ & 2 & 2 & 2 & 2 \\
\hline $7 / 71^{\text {st }}$ spray & 7 & 7 & 7 & 7 \\
\hline $14 / 7$ & 18 & 4 & 11 & 4 \\
\hline $21 / 7 \quad 2^{\text {nd }}$ spray & 44 & 7 & 24 & 5 \\
\hline $28 / 7$ & 50 & 4 & 24 & 4 \\
\hline July mean & 24.2 & 4.8 & 13.6 & 4.4 \\
\hline$\%$ reduction & - & 80.17 & 43.80 & 81.82 \\
\hline $4 / 8 \quad 3^{\text {rd }}$ spray & 60 & 5 & 36 & 4 \\
\hline $11 / 8$ & 65 & 4 & 37 & 4 \\
\hline $18 / 8$ & 69 & 5 & 37 & 4 \\
\hline $25 / 8$ & 76 & 5 & 28 & 4 \\
\hline August mean & 67.5 & 4.75 & 34.5 & 4 \\
\hline$\%$ reduction & - & 92.96 & 48.89 & 90.07 \\
\hline $1 / 9$ & 77 & 5 & 27 & 4.5 \\
\hline $8 / 9$ & 73 & 4.5 & 25 & 4 \\
\hline $15 / 9$ & 71 & 4 & 22 & 3.5 \\
\hline September mean & 73.67 & 4.5 & 24.67 & 4 \\
\hline$\%$ reduction & - & 93.89 & 66.51 & 94.57 \\
\hline General mean & $55.12^{a}$ & $4.68^{c}$ & $24.26^{b}$ & $4.13^{\mathrm{C}}$ \\
\hline L.S.D.between treatments & \multicolumn{4}{|c|}{1.08} \\
\hline F value & \multicolumn{4}{|c|}{$1.09^{\mathrm{ns}}$} \\
\hline General reduction & - & $91.15^{b}$ & $55.99^{c}$ & $92.51^{a}$ \\
\hline F value & \multicolumn{4}{|c|}{$6.69^{\mathrm{ns}}$} \\
\hline
\end{tabular}

As illustrated in Table (4), highly significant differences were obtained in the mean infestation of $E$. insulana between treatment with Patron and both Trebon and Selecron treatments in case of using motor sprayer Cifarilli. Earliest incidence of the spiny bollworm larvae of the experimental trails was on June, $30^{\text {th }}$. Number of spiny bollworm larvae was mostly lower in the two treatments of Selecron and Trebon than Patron treatment. Reduction means in the infestation percentages of bollworm larvae of plots treated with Selecron, Patron and Trebon attained $79.01,42.56$ and $81.57 \%$ during July; $92.70,47.88$ and $93.7 \%$ during August; 93.67, 66.02 and 94.30 during September and $91.13,55.19$ and $92.20 \%$ in the whole season, respectively. 
Table (4): Effect of spraying three tested compounds on infestation percentages by spiny bollworm $E$. insulana larvae during season 2014 with motor sprayer Cifarilli.

\begin{tabular}{|c|c|c|c|c|}
\hline $\begin{array}{l}\text { Treatments } \\
\text { Inspection date }\end{array}$ & Control & Selecron & Patron & Trebon \\
\hline $30 / 6$ & 2 & 2 & 2 & 2 \\
\hline $\begin{array}{ll}7 / 7 & 1^{\text {st }} \text { spray }\end{array}$ & 7 & 7 & 7 & 7 \\
\hline $14 / 7$ & 18 & 4.3 & 11.4 & 4 \\
\hline $21 / 7 \quad 2^{\text {nd }}$ spray & 44 & 7.4 & 24.5 & 5.2 \\
\hline $28 / 7$ & 50 & 4.7 & 24.6 & 4.1 \\
\hline July mean & 24.2 & 5.08 & 13.9 & 4.46 \\
\hline$\%$ reduction & - & 79.01 & 42.56 & 81.57 \\
\hline $4 / 8 \quad 3^{\text {rd }}$ spray & 60 & 5.3 & 36.4 & 4.3 \\
\hline $11 / 8$ & 65 & 4.1 & 37.5 & 4.2 \\
\hline $18 / 8$ & 69 & 5.2 & 37.8 & 4.1 \\
\hline $25 / 8$ & 76 & 5.1 & 29 & 4.3 \\
\hline August mean & 67.5 & 4.93 & 35.18 & 4.23 \\
\hline$\%$ reduction & - & 92.70 & 47.88 & 93.73 \\
\hline $1 / 9$ & 77 & 5.2 & 29 & 4.7 \\
\hline $8 / 9$ & 73 & 4.6 & 26 & 4.3 \\
\hline $15 / 9$ & 71 & 4.2 & 23 & 3.6 \\
\hline September mean & 73.67 & 4.67 & 25.03 & 4.2 \\
\hline$\%$ reduction & - & 93.67 & 66.02 & 94.30 \\
\hline General mean & $55.12^{a}$ & $4.89^{C}$ & $24.70^{b}$ & $4.30^{\mathrm{C}}$ \\
\hline L.S.D. between treatments & \multicolumn{4}{|c|}{1.51} \\
\hline $\mathrm{F}$ value & \multicolumn{4}{|c|}{$0.44^{\text {ns }}$} \\
\hline General reduction & - & $91.13^{b}$ & $55.19^{c}$ & $92.20^{a}$ \\
\hline F value & \multicolumn{4}{|c|}{6341.95} \\
\hline
\end{tabular}

-Comparison on basis of controlling index and potency levels:

It seams always convenient to consider the efficiency on the degree of toxicity of different insecticides by comparing them with a standard compound. In the present work, comparisons among the tested compounds are based on the control index method developed by Khidr et al. (2003) and the potency levels expressed as number of folds frequently used in this respect. Control index was obtained by comparing the mean reduction percentages in standard compound with each of the tested insecticides. The following equation was employed to determine the control index:

Control index $=$ mean of $\%$ reduction of tested compound $/$ mean of $\%$ reduction of standard insecticide $X 100$.

The potency levels expressed as number of folds were determined by divided reduction percentages of the tested insecticides by the standard showed the least reduction percentages. 
On the other ground of the control index as shown in Table (5), the efficiency of Selecron and Patron insecticides recorded 98.92 and $60.52 \%$ as effective to Trebon against $E$. insulana respectively when the micron ULVA equipment was used for the three insecticides application and 98.84 and $55.19 \%$; respectively in case of using Cifarilli motor sprayer for the used insecticides application.

Concerning the potency levels expressed as number of folds compared with the efficiency of Patron insecticide, the efficiency of selecron and Trebon attained 1.63 and 1.65 times as he efficacy of Patron; respectively in case of using micron ULVA equipment and 1.65 and 1.67 times as to Patron insecticide, respectively when the Cifarilli motor sprayer was used for the three insecticides application.

Table (5): Relative comparison between three insecticides applied by micron ULVA and Civarilli motor sprayer for controlling $E$. insulana in cotton field.

\begin{tabular}{|l|c|c|c|c|}
\hline \multirow{2}{*}{$\begin{array}{l}\text { Insecticide } \\
\text { used }\end{array}$} & \multicolumn{2}{|c|}{ Control index } & \multicolumn{2}{c|}{ Potency levels } \\
\cline { 2 - 5 } & $\begin{array}{c}\text { Micron } \\
\text { ULVA }\end{array}$ & $\begin{array}{c}\text { Cifarilli } \\
\text { motor } \\
\text { sprayer }\end{array}$ & $\begin{array}{c}\text { Micron } \\
\text { ULVA }\end{array}$ & $\begin{array}{c}\text { Cifarilli } \\
\text { motor } \\
\text { sprayer }\end{array}$ \\
\hline Selecron & 98.92 & 98.84 & 1.63 & 1.65 \\
\hline Patron & 60.52 & 55.19 & 1.00 & 1.00 \\
\hline Trebon & 100 & 100 & 1.65 & 1.67 \\
\hline
\end{tabular}

In a similar study Salem (2002) recorded that the chemical insecticide (Herculis) was the most effective in reducing the infestation and larval content in green cotton bolls. Also, Al-Shannaf (2010) found that all the tested sprays (Profenofos, S-fenvalerate and Chlorpyrifos methyl caused highly decreasing in cotton bollworms larvae compared with untreated area.

Also, Abdalla (1991) stated that the effects of chemical control programs on the rate of infestation of cotton bolls by the E. insulana in Egypt. The obtained results revealed that three or four sprays through the season caused a satisfactory decrease of infestation and loss of yield. Simwat and Dhawan (1992) assessed the efficacies of conventional insecticides were the most compounds potent against cotton bollworms, while diflubenzuron alone reduced pest infestation, although diflubenzuron was less effective than the other insecticides. Abdel Megeed (2008) found that foliar treatment of Eastena Aminofert with spinosad and chloropirifos reduced levels of spiny bollworm infestation.

The optimum spectrum of droplets for controlling insects of field crop should be sized between 140 and $200 \mu \mathrm{m}$ (VMD) with number not less than 30 and 50 droplets $/ \mathrm{cm}^{2}$ distributed homogeneously on the treated target Himel (1969). The following general trends could be extracted from the obtained data and may help in better understanding to the experimental results, Table (6). 
In this work, the minimum size of measured spots was however about $50 \mu \mathrm{m}$. This is due to the limited capability of the available technique of measurement, which means logically that a lot of invisible fine spots smaller than $50 \mu \mathrm{m}$ should occurred within the measured spots. This might clarify the appearance of certain non-reasonable killing results in some experimental treatments. The range of droplets spectrum (VMD and N/cm ${ }^{2}$ ) deposited on the natural targets by using total recommended dose, insecticides used were $140 \& 169 \mu \mathrm{m}$, and $14 \& 276 \mathrm{~N} / \mathrm{cm}^{2}$.

Table (6)Spraying coverage on cotton plants and ground holders produced by certain ground spraying equipment, at season 2014 using total recommended dose rate tested insecticides against Earias insulana at Qalubiya Governorate.

\begin{tabular}{|c|c|c|c|c|c|c|c|c|c|c|c|c|}
\hline Equipment & \multicolumn{6}{|c|}{ Economy Micron ULVA } & \multicolumn{6}{|c|}{$\begin{array}{c}\text { Cifarilli } \\
\text { Knapsack-motor-sprayer }\end{array}$} \\
\hline $\begin{array}{l}\text { Application } \\
\text { rate L./fed. }\end{array}$ & \multicolumn{6}{|c|}{15} & \multicolumn{6}{|c|}{20} \\
\hline Insecticide & \multicolumn{2}{|c|}{ Selecron } & \multicolumn{2}{|c|}{ Patron } & \multicolumn{2}{|c|}{ Trebon } & \multicolumn{2}{|c|}{ Selecron } & \multicolumn{2}{|c|}{ Patron } & \multicolumn{2}{|c|}{ Trebon } \\
\hline & $\mathrm{N} / \mathrm{cm}^{2}$ & VMD & $\mathrm{N} / \mathrm{cm}^{2}$ & VMD & $\mathrm{N} / \mathrm{cm}^{2}$ & VMD & $\mathrm{N} / \mathrm{cm}^{2}$ & VMD & $\mathrm{N} / \mathrm{cm}^{2}$ & VMD & $\mathrm{N} / \mathbf{c m}^{2}$ & VMD \\
\hline Upper level & 172 & 157 & 180 & 157 & 154 & 163 & 268 & 156 & 276 & 149 & 272 & 158 \\
\hline Middle level & 170 & 165 & 140 & 150 & 134 & 164 & 252 & 142 & 268 & 147 & 260 & 154 \\
\hline Lower level & 216 & 162 & 104 & 158 & 120 & 166 & 240 & 154 & 184 & 140 & 222 & 148 \\
\hline Mean & 156 & 161 & 141 & 155 & 136 & 164 & 253 & 151 & 243 & 145 & 251 & 153 \\
\hline Ground & 31 & 159 & 23 & 155 & 14 & 162 & 44 & 160 & 53 & 169 & 48 & 164 \\
\hline $\begin{array}{l}\% \mathrm{~N} / \mathrm{Cm}^{2} \text { on } \\
\text { ground } \\
\text { (spray lost) }\end{array}$ & 6.6 & - & 5.4 & - & 3.4 & & 5.8 & - & 4.8 & - & 6.4 & - \\
\hline
\end{tabular}

The spray lost on ground, between plants, was the only measured loss, whereas other sources of loss such as by wind (drift), evaporation,... etc, were not subjected to investigation throughout this work.

The obtained results in Table (6) confirmed the positive relationship between spray volume and droplet sizes, which affects negatively the number of formed droplets. Taking into account that the main studied factors affecting the spraying, were the rate of insecticide application, the specifications of the pesticide, its formulation and its mode of action, age of cotton plant and level, position of deposited spray and the meteorological conditions during application of the treatments. The percentages of number of droplets $/ \mathrm{cm}^{2}$ in the case of Cifarilli Motor sprayer were 21.4, 20.8\& 20.4 in the case of Selecron, Patron and Trebon, respectively. But, in the case of Economy Micron ULVA sprayer the percentage of the same droplets number/cm ${ }^{2}$ were 13.3, 11.9 \& 11.2 for Selecron, Patron and Trebon, respectively.

In the other hand, there were no significant differences between both the distribution percentages of droplet sizes and the droplets number $/ \mathrm{cm}^{2}$ at all targets (cards on cotton plants and cards on ground between cotton plants). 
In the same time, there were a significant differences between both the distribution percentages of droplet sizes (LSD= 0.82 for equipment, 1.16 for levels and 1.006 for compounds) and for the droplets number/cm ${ }^{2}$ (LSD=0.8 for equipment, 1.13 for levels and 0.98 for compounds).

Relations between spray quality and bioresidual effects of certain insecticides applied early in cotton season.

Data in Table (6) showed that, Selecron at its recommended rate 750 $\mathrm{ml} / \mathrm{fed}$., Patron its recommended rate $20 \mathrm{gm} / 20 \mathrm{~L}$., and + its recommended rate was $625 \mathrm{~cm} / 100 \mathrm{~L}$., using two ground spraying equipment and varied spraying volumes depending on the sprayer used. Data indicated that, in general all the tested spraying equipment gave satisfactory coverage on cotton plants i.e. more than 50 droplets $/ \mathrm{cm}^{2}$, and droplet sizes ranged from 140 to $169 \mu \mathrm{m}$ (VMD). The difference in the mortality percentage was due to the different mode of action of the three insecticides.

A satisfactory coverage was obtained on cotton plants, the droplet spectrum was obtained in field experiment was agreed with the optimum droplet sizes which mentioned by Himel (1969). The best obtained result was $15 \mathrm{~L} / \mathrm{Fed}$. As spray volume, $156.9 \mu \mathrm{m}$ and $155.5 \mathrm{droplets} / \mathrm{cm}^{2}$, these results agreed with (Himel et al., 1969) in the optimum droplet size to control cotton leaf worm in the cotton fields by ground equipment. Tribon and Selecron revealed the best bio-efficiency results followed with Patron with the two tested sprayers (Cifarilli) motor sprayer (20 L./fed.) and Economy Micron ULVA sprayer (15 L./fed.), these results agreed with Hindy et al., (2004) and Genidy et al., (2005) which recommended KZ oil and Pyriproxyfen followed by Agerin using low volume spraying because of reducing the time lost in process filling the machines, improve the homogeneity of the spray solution on the plant leaves and saving the lost spray of the ground and Bakr et al.,(2014). The data showed that Economy Micron ULVA sprayer (15 L./fed.) is the best equipment to control Spiny bollworm on cotton plants. Also, the lowest spray volume and the lowest percentage of lost spraying between plants; these results were agreed with Hindy et al., (1997) and (2011) who mentioned that, there was a positive relationship between rate of application and spray lost on ground. Generally, Patron and Trebon are recent insecticides that avoid the activity of Spiny bollworm on cotton plants, and safe the children who were picked manually egg masses during hot days and saving also the traditional insecticides which injures the human body and the agricultural environment. 


\section{REFERENCES}

Abdalla, E. F. (1991): Effect of sowing date and certain chemical control programs against the cotton bollworms, Pectinophora gossypiella (Saund.) and Earias insulana (Boisd.). Bull. Enomol. Soc., Egypt, Economic series, 19:157-165.

Abdel Megeed, A. (2008): new measures for the control of cotton bollworms with references to the side effect on certain soil enzyme. Middle Eastern and Russian J. of Plant Science and Biotechnology.2(2):38-43.

Abdul-Naser., S. M., M. Megahed and A. A. M. Mabtouk (1973): A study on the host plants of the Spiny bollworm Earias insulana (Boisd). Bull. Soc. Ent. Egypt. (56): 151-16.

Al-Shannaf, H. M. H. (2010): Effect of sequence control sprays on cotton bollworms and side effect on some sucking pests and their associated predators in cotton fields. Egypt. Acad. J. biolog. Sci., 3 (1): 221 - 233.

Bakr, R. F.; Hindy, M.A., Ahmed, N. S., Genidy, N. A. and Anddar, R. A. (2014): Field comparison between droplet distribution and the bioresidual activity of different insecticides against Spodoptera littoralis (Boisd) by using certain ground spraying equipment on cotton plants. J. Egypt. Acad. Soc. Biolo. Sci. 7(1):187-193.

Burt, E.C.; Lloyed, E.P.; Scott. W.P.; Mccoy, J.R. and Tingles, F.C. (1970): Boll weevil control with insecticide applied in sprayers with narrow spectrum droplet sizes. J. Econ. Entomol., 63 (2): 265-270. Entomol., 62 (4): 919-925.

El- Shenawy. A.M.R. 2009: Evaluation of some pesticides against pink bollworm Pectinophora gossypiella (Saunders). M.Sc. thesis, Faculty of Science, Al-Azhar University 166 pp.

Genidy, N.A.; Bakr, R. F., Hindy, M. A. and Dar, R. A. (2005): Bioresidual activity certain insecticides against Spodoptera littoralis (Boisd) by using low volume ground spraying equipment on cotton plants.

Henderson, C.F. and Tilton, E.W. (1955): Tests with acaricides against the brown wheat mite. Journal Econ. Entomol., 48: 157-161.

Himel, C.M. (1969): The optimum size for insecticide spray droplets. J. Econ. Entomol., 62 (4): 919-925.

Himel, C.M. and Moore, A.D. (1969): Spray droplet size in the control of Spruce. budworm, Boll weevil, Bollworm.

Hindy, M.A. (1989): Residual activity of certain insecticides as affected by aerial application parameters. Ph. D. Thesis. Fac. Ageric., Ain Shams Univ., Egypt, 177 pp.

Hindy, M.A. (1992): Qualitative distribution of watery dyed spray produced by certain ground sprayers in cotton. Bull. Ent. Soc., Egypt 19:221-7.

Hindy, M.A.; El-Sayed, A.M., Abd El-Salam, S.M. and Samy, M.A. (1997): Qualitative Assessment of certain insecticides applied by different ground sprayers against whitefly, Bemicia tabaci (Geen.) on eggplanthe. Egypt. J. Agric. Res., 75 (3): 565-577. 
Hindy, M.A.;Bakr, R.F.; Genidy, N.A. and Dar, R.A. (2004): Qualitative distribution of certain insecticides deposits and artificial targets on the cotton leafworm larvae by using certain ground spraying equipment .

Hindy, M.A.; Bakr,R.F., Guniedy, N.A., Ahmed, N.S. and Dar, R. A. (2011): Evaluation of certain ground spraying equipments by the mean of qualitative distribution of certain insecticides deposits and artificial targets on the cotton leaf worm on cotton plants. .Journal of American Scince.Vol.7(12):713-719.

Kandil, A. A. Mervat; A.F. Ahmed and Hemat Z. Moustafa (2013): Toxicological and biochemical studies of lufenuron, chlorfluazuron and chromafenozide against Pectinophora gossypiella (Saunders).Egypt. Acad. J. Biolog. Sci., 4 (1): 37- 47.

Khidr, A. A.; Abdeen, S. A. O.; Eissa, M.A.; A.M.H. (2003): Potency levels: Evaluation of some insecticides and their joint action aginst the cotton leafworm, Spodoptera littoralis on lettuce vegetable plant, Lactuca sativa L. Annals of Agric. Sc. Moshtohor, 41(3):1323-1330.

Salem, M.S. (2002): Evaluation to the efficacy of some recent approaches used for controlling pink and spiny bollworms in the field. M.Sc. Thesis, Fac. Agric. (Moshtohor), Zagazig Uni.

Salem, M.S. (2008): Inducing resistance of cotton plants against cotton bollworms. Ph. D. Thesis, Fac. Agric. (Moshtohor), Zagazig Uni.

Simwat, G.S. and A.K. Dhawan (1992): Efficacy of diflubenzuron and in combination with insecticides for control of bollworms on different varieties of upland cotton Gossypium hirsutum). Indian J. of Agrc. Sci., 62 (6):424-426.

Zaki, A.A.T. (2006): Toxicological and biological studies on bollworms. Ph.D. Thesis Fac. Agric., Benha Univ.

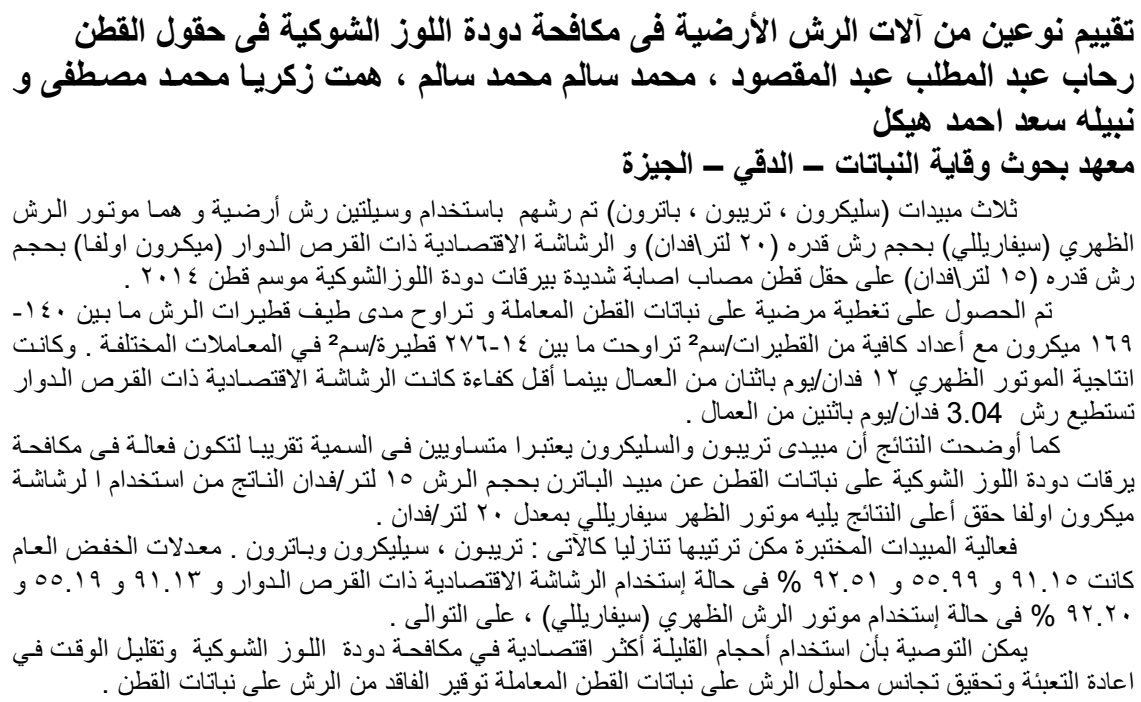

